\title{
Study of chitosan addition in the PVP/PVAL polymeric blend.
}

\author{
Mauro C. Terence ${ }^{1, a}$, Leila F. de Miranda ${ }^{1, b}$, Sonia B. Faldini ${ }^{1, c}$, Paula J. de Castro ${ }^{1, d}$ \\ ${ }^{1}$ Universidade Presbiteriana Mackenzie - UPM, São Paulo-SP \\ Departamento de Engenharia de Materiais \\ Rua da Consolação 930, Prédio 6. Consolação. São Paulo. S.P. CEP: 01302-907 \\ amauroterence@yahoo.com.br, ${ }^{\mathrm{a}}$ engmateriais@mackenzie.com.br, ${ }^{\mathrm{c}}$ sfaldini@yahooo.com.br, \\ dpaula.jcastro@yahoo.com.br
}

Keywords: Blend, Chitosan, PVP, PVAL.

\begin{abstract}
The main objective of this project is the study of the addition of chitosan in the polymeric blend of PVP/PVAL to get a biocompatible hydrogel that can be used as a system of controlled release of drugs. The polymeric blend usage is a recent development that expanded the applications of the polymers, due to the improvement of the properties of a single polymer even if they appear to be conflicting. PVP and PVAL were chosen because they present the main required characteristics to the formation of a hydrogel, such as water absorption and crosslinked formation. The flexibility of the PVP was added with the mechanical resistance of the PVAL. The chitosan, biological active polymer molecules, addition is to increment the interaction between the hydrogel and the organism. With the concentrations of PVP and PVAL defined, solutions with different levels of chitosan were made to check which presented better properties.
\end{abstract}

\section{Introduction}

The polymer systems or polymer blends have enabled polymers new applications that previously were exclusively of homopolymers and copolymers, and also innovative uses. The mixture of polymers aims better properties of the separated material, such as stiffness, impact resistance, and dimensional stability at high temperatures, flame resistance and resistance to aging. It is possible to combine some of these qualities, including those that are apparently conflicting, for example, increased impact resistance or tensile strength, increasing flexibility and dimensional stability [1].

The PVP and PVAL were choosen because they are used as biocompatible hydrogels and present the main required characteristics to the formation of a hydrogel, such as crosslinking and water absorption, favored by the presence of $\mathrm{N}$ of the PVP and the OH of the PVAL. The PVAL despite being a synthetic polymer, is used as basic material for many applications in biomedicine, 
once it is non toxic or carcinogenic. But the main objective is to combine the flexibility of PVP with the mechanical strength of PVAL, since it is able to form stronger films, obtaining a hydrogel with improved properties for application in controlled release systems for drugs. [2].

To improve the interaction of the hydrogel with the body, it is possible to incorporate other biologically active molecules such as polymeric chitosan, a natural polymer that interacts with the body suffering degradation in vivo, resulting in nontoxic products[3]

Chitosan is a natural polymer derived from the process of deacetylation of chitin, which is considered the second most abundant polysaccharide in nature. Chitosan is mainly obtained from the distillation of chitin by alkaline deferent methods, although it can occur naturally in small quantities from certain species of fungi. The polymer chain of chitosan is mainly formed by units (1-4) 2-amino-2-deoxy-D-glucopyranose, showing a polymer chain similar to. $[4,5,6]$

In this work was studied the addition of differet concerntrtions of a Chitosan solution in a defined PVP/PVAL solution, to compare the mechanical charactericts that the blends will present.

\section{Methodology}

Solutions containing 25\%w PVP and 75\%w PVAL were prepared and the chitosan in an Acetic Acid solution was added according to Table 1. The proportion is presented in mass. The solution was homogenaized and poured into Petri Plate and kept at room temperature until dry.

\begin{tabular}{|l|l|l|}
\hline Film number & $\begin{array}{l}\text { PVP/PVAL } \\
\text { solution }\end{array}$ & $\begin{array}{l}\text { Chitosan } \\
\text { Solution }\end{array}$ \\
\hline 1 & $25 \%$ & $75 \%$ \\
\hline 2 & $50 \%$ & $50 \%$ \\
\hline 3 & $75 \%$ & $25 \%$ \\
\hline 4 & $100 \%$ & \\
\hline 5 & & $100 \%$ \\
\hline
\end{tabular}

Table 1. Concetration of PVP/PVAl and Chitosan in the prepared solutions.

The films characterization was realized first with a qualitative visual analysis, which was made during removal of the films from the Petri Plate. Then tensile tests were realized to obtain the mechanical characteristics. 


\section{Results and discussion}

The results and comments of the qualitative visual analysis appears is Table 2.

\begin{tabular}{|c|c|c|}
\hline Film number & Picture & Characteristics \\
\hline 1 & & Fragile, rigid. \\
\hline 2 & & Fragile, rigid. \\
\hline 3 & & Homogeneus film \\
\hline 4 & & Homogeneus film \\
\hline 5 & & No film. \\
\hline
\end{tabular}

Table 2 - Qualitative visual analysis.

The results of the tensile test are show in Figure 1. The graphics compare the mechanical properties of a PVP/PVAL blend and the film with the PVP, PVAL and chitosan. 


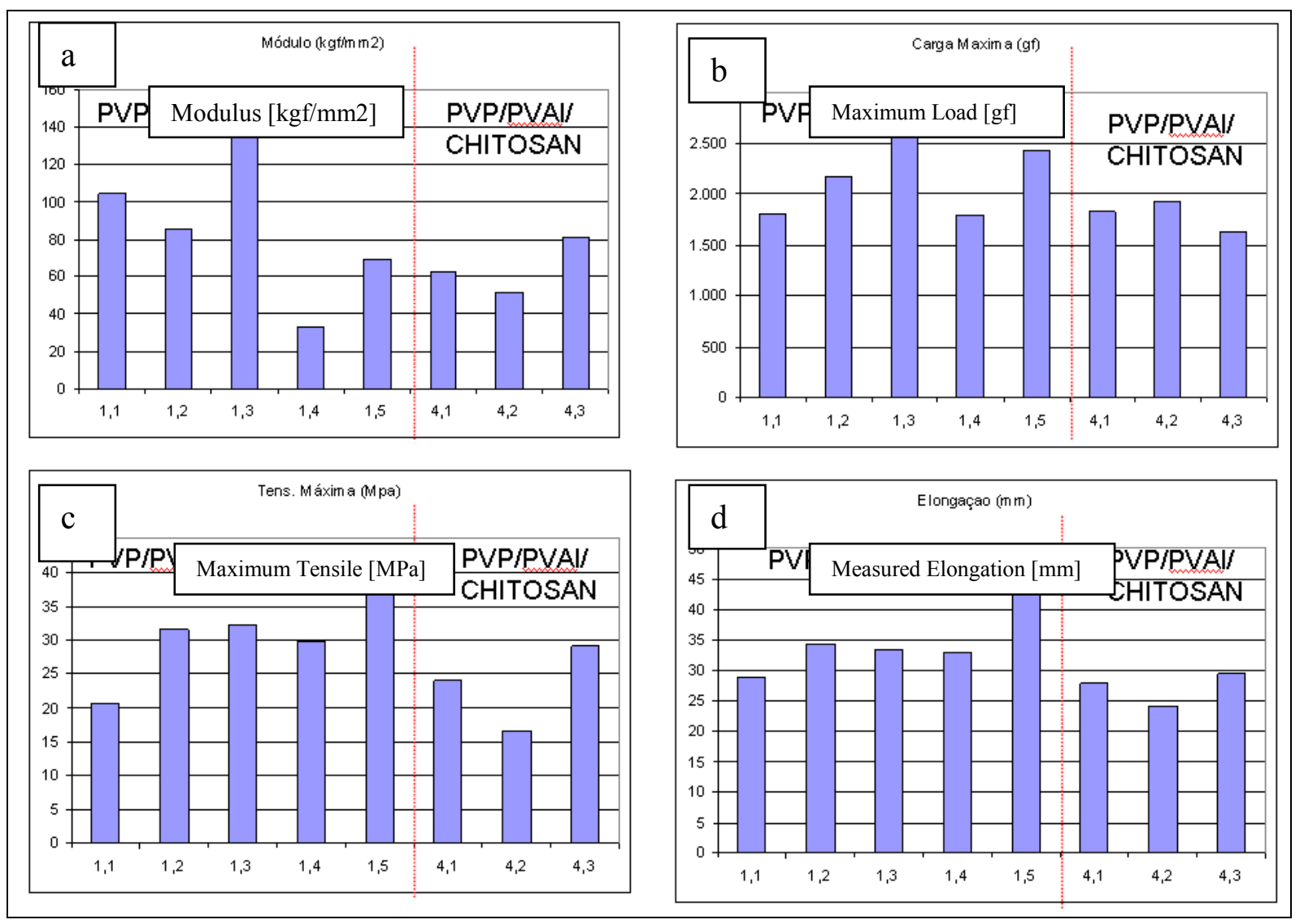

Figure 1 - Results obtained by tensile tests.

It is possible to confirm that in all chacarcteriscts, (a) Modulus [kgf/mm2], (b) Maximum Load [gf], (c) Maximum Tensile [MPa] and (d) Measured Elongation [mm] the addition of Chitosan in the PVP/PVAL blend does not increase the properties the PVP/PVAL blend present.

\section{Conclusion}

It is possible to observe that an homogeneus film is formed with the addition of Chitosan in the PVP/PVAL blend, with $75 \% \mathrm{w}$ of PVP/PVAL solution and $25 \% \mathrm{w}$ of the Chitosan solution, but, with the method presented the addition of Chitosan does not increase the properties of the PVP/PVAL blend.

\section{REFERENCES}

[1] CASTRO, P.J; TERENCE, M.C. Estudo da formação de blendas poliméricas de PVP/PVAL para a formação de hidrogéis utilizáveis em sistemas de liberação controlada de drogas. Relatório Projeto PIBIC-UPM- SP, São Paulo, 2007. 
[2] YOSHII, F. et al. Heat Resistance Poly(Vinyl Alcohol) Hydrogel Radiat. Phys. Chem. v. 46, n. 2, p. 169-174, 1995.

[3] ONISHI, H. MACHIDA, Y. Biodegradation and distribution of water-soluble chitosan in mice. Biomaterials. 20(2):175-82. Department of Clinical Pharmacy, Hoshi University, Tokyo, Japan, 1999.

[4] CASTRO, P.J; TERENCE, M.C. Estudo do efeito da adição de quitosana em blendas poliméricas de PVP/PVAL. Relatório Projeto PIBIC-UPM- SP, São Paulo, 2008.

[5] RINAUDO, M. Chitin and chitosan: Properties and applications. Progr. Polymer.Sci., v. 31, p. 603-632, 2006.

[6] REN, D.; YI, H.; WANG, W.; MA, X. The enzymatic degradation and swelling properties of chitosan matrices with different degrees of N-acetylation. Carbohydr. Res., v. 340, p. 2403-2410, 2005. 